\title{
PHYTOPHTHORA DECLINE OF ALDER (ALNUS SPP.) IN EUROPE
}

\author{
by Thomas L. Cech
}

\begin{abstract}
In several European countries, alder (Alnus glutinosa and $A$. incana) growing along rivers is threatened by a decline that is consistently related to stem necrosis caused by Phytophthora. It was first thought to be a form of Phytophthora cambivora, but morphological differences as well as its homothallism indicate a new species. High pathogenicity on $A$. glutinosa and $A$. incana have been proven by experiments in Great Britain, the Netherlands, and Germany. At present the disease is widespread in Great Britain, whereas in Denmark, France, Germany, Ireland, the Netherlands, and Sweden only a few cases have been reported. In Austria, decline of $A$. glutinosa was observed in 1986 and 1996. Symptoms include simultaneous crown decline, preceded by abnormally small leaves, stem necrosis, and exudates from the bark resulting in tarry spots. Cracks at the stem base with strong callus formation suggest earlier attacks or mechanical injuries prior to infection. Several times Phytophthora was isolated, and it showed high similarity to British strains. In addition, other bark-attacking fungi were identified, among them Phomopsis alnea, Ophiovalsa suffusa, Pleomassaria holoschista, and Pezicula cinnamomea. Probable predispositions, such as drought periods followed by heavy rainfall, and severe winter frost are discussed along with practical control measures, such as fungicide treatment.

Keywords. Alnus spp.; decline; Phytophthora; predispositions.
\end{abstract}

Alders in Europe are not often the focus of forest protection concerns because they are of minor importance to the forest economy; however, the ecological value of the genus is well recognized. The two main species are Alnus glutinosa (common alder) and $A$. incana (grey alder), both growing mainly in damp woodlands or lining streams and rivers, contributing to the stabilization of the banks. More rarely, they can be found in pure stands. Alnus cordata (Italian alder), derived from Southern Italy and Corsica, is widely planted as an ornamental. Alnus viridis (European green ash) is a shrub species found in mountainous to subalpine altitudes.

Although decline and dieback have been known for more than a hundred years, these events are often overlooked because of the vigorous growth of common and grey alder and their ability to sprout from the stem base. Early reports date from the last century, when alder dieback occurred in Denmark (Rostrup 1889), Germany, and Belgium (Nypels 1900). During the first half of the 20th century, problems with alder were quite common in Germany (v. Oertzen 1901; Appel 1904; Bansi 1924; Münch 1932, 1936). Most cases of alder diseases affecting the whole tree are reported as dieback phenomena and have mainly been interpreted as the result of attacks of pathogenic microfungi due to abnormal changes in the groundwater level, frost, or unsuitable provenances of the plants (Münch 1936). Alder dieback in northern Britain has been a problem for nearly 20 years (Gregory et al. 1996).

In 1993, an apparently new form of alder disease occurred along several small rivers in the southeast region of the United Kingdom (Gibbs 1995). Tests revealed a new species of the genus Phytophthora was responsible for girdling common alders at their stem base. This was the first finding of a Phytophthora species pathogenic for alder. In the same year, similar phenomena were observed in lower Saxony (Germany) and again Phytophthora was isolated from diseased trees (Hartmann 1995). More recently, cases of alder decline associated with Phytophthora were reported in Austria, Denmark, France, and Sweden (Cech 1996; Thinggaard 1996; Forestry Commission 1997).

Most of the diseased trees are common alder. Grey alder and Italian alder are affected more rarely. There are no reports of cases on European green ash (alder). Most of the diseased trees grow along streams or rivers and are subject to occasional flooding. There are, however, stands where no flood occurred before the appearance of the disease (e.g., orchard shelterbelts and nurseries).

This report describes findings from different European countries as well as results from initial investigations in Austria concerning symptomatological facts. 


\section{Geographic Extent of the Disease}

Phytophthora disease of alder is, so far, epidemic only in the United Kingdom. Between 1994 and 1996, it spread all over England up to the River Spey in Scotland (Forestry Commission 1997). British investigators report that the number of trees killed by Phytophthora doubles every year. Thus, in 1996 about $2 \%$ of the alders died (Forestry Commission 1997). In other European countries, alder decline seems to be a localized problem; therefore, no quantitative disease loss data are available. In Austria, 4 small rivers are lined by common alder trees currently suffering from the disease. The areas are all located in upper Austria, in a predominantly agricultural area. Along each of the rivers, approximately 500 trees show symptoms of the disease. Phytophthora was isolated in 1996 in two of the stands (Cech 1996).

In June 1997, investigation plots were established along the 4 rivers. All trees within a 0.18-km (0.3-mi) section were examined (about 100 trees). This investigation revealed that the percentage of diseased trees was between $36 \%$ and $77 \%$ and the percentage of dead trees was below $5 \%$. Symptoms of declining trees were recorded, with special regard to bark necroses on the stem.

\section{Symptoms}

Crown symptoms appear as a consequence of bark necrosis on the stem base. Usually, the whole crown is affected all at once, although dieback of individual branches can be quite common as an additional symptom (e.g., on about one-third of the alders classified as diseased in the 4 investigation plots). The most characteristic decline symptom is abnormally small and sparse leaves. Initially the same color as those of healthy trees, they soon become yellow and fall prematurely. Furthermore, approximately $40 \%$ of the diseased trees in Austria show extreme fruiting. On the stem, brown exudates (up to approximately $2 \mathrm{~m}$ [6.5 ft] high) are extruded over the bark surface, leaving tarry spots when drya common symptom, although not consistently present (35\% of the diseased trees in the investigation plots).

Crown decline or tarry spots alone can be the result of other damaging factors, but both symp- toms occurring together reliably indicate the presence of a basal stem necrosis produced by Phytophthora. After removing the outer bark layers around the tarry spots a red brown to black discolored necrotic area is exposed. It is mostly tongue-shaped, growing upwards as well as in a periclinal direction. Phytophthora can be isolated from the rim of growing necroses by cutting out bark chips and culturing the fungus by the apple method (Brasier and Strouts 1976).

Longitudinal cracks in the bark of the stem appear, sometimes with strong callus formation. These symptoms are believed to be a consequence of repeated attacks of the fungus and wound-closing attempts of the tree (Hartmann 1995). In Austria, this feature varies strongly in its expression within the stands. Frequently, epicormic sprouts are produced in the area above the bark necrosis.

\section{Phytophthora and Other Fungi}

The alder Phytophthora has been shown to be related to Phytophthora cambivora (Gibbs 1995; Hartmann 1995; Brasier et al. 1996); however, it differs in its homothallic nature and several morphological features (Brasier et al. 1996). All strains turned out to be pathogenic on seedlings and on 6-year-old trees on $A$. glutinosa, $A$. incana, $A$. cordata, and $A$. rubra, as shown by pathogenicity experiments in the United Kingdom, the Netherlands, and Germany (Gibbs 1995; Hartmann 1995; Van Dijk 1996).

In the Netherlands, Phytophthora citricola was isolated from trees with decline symptoms and from soil samples. Pathogenicity tests for Phytophthora on alder seedlings were positive, but so far no causal connection between the alder decline and this species has been proven (Van Dijk 1996).

According to observations in the United Kingdom, Denmark, Germany, and Austria, infection often begins at the stem base and, more rarely, on main roots (Lonsdale 1996; Thinggaard 1996). In the United Kingdom, the infection often occurs on the side of the tree exposed to the river bank, especially when the trees are bent upwards as a result of erosion of the bank. It is believed that the fungus enters fine roots in this area (Lonsdale 1996). In Austria, nearly all necroses spread from 
the water-exposed side of the tree. Further details of the infection mode are not known.

The flora of microfungi colonizing dying or dead alder bark is well known (Truter 1947; Domanski and Kowalski 1987). No species found so far in connection with alder decline showed an aggressiveness comparable to the alder Phytophthora. Investigations of fungi colonizing bark tissues on selected trees of the 4 Austrian investigation plots showed that Ophiovalsa suffusa is occasionally responsible for local bark necroses on the stems of trees weakened by Phytophthora. These necroses accelerate the decline. Other species, such as Phomopsis alnea, Pleomassaria holoschista, and Pezicula cinnamomea, were observed in these plots, but probably are more saprophytic. There are no published reports of the occurrence of Hypoxylon fuscum, which can produce similar bark necroses on grey alder (Domanski and Kowalski 1987).

\section{Environmental Factors Likely Favoring Disease}

Although there is evidence of the destructive character of the new alder Phytophthora, factors predisposing the trees to infection are unknown. Long-lasting drought periods followed by heavy rainfall leading to stagnant water are known to trigger Phytophthora epidemics (Day 1938), but not all stands with alder decline suffered from these climatic extremes. The same problem arises with winter freeze: Cases of alder decline in Austria during the years 1985 and 1986 (with symptoms similar to those found at present) were scattered along small rivers with concentrations in sites with severe winter freeze the two previous years. No comparable situation can be found in connection with the present diseased stands. According to investigations in the United Kingdom, the occurrence of the disease shows a slight correlation with pollution parameters of the rivers, especially with oxidized nitrogen. If tree stress due to increasing levels of nutrients was the main reason for the disease, a widely distributed outbreak could be expected in Europe within the next several years. There are, however, alders dying along unpolluted rivers, so this might be only a contributing factor.
Apart from the few disease foci not in contact with free water, the infectious inocula are likely carried by water. Whether they need wounds to invade the stem is unclear but this subject is under investigation at present. Diseased trees in Austria sometimes show broad lesions at their stem base, from which the necrosis develops. Because floods commonly carry objects that bump against the trees, it is conceivable that these lesions are due to mechanical injuries prior to the infection by Phytophthora rather than being the result of earlier attacks of the fungus.

\section{Disease Management}

According to a recent guideline by the Forestry Commission of the United Kingdom, felling of diseased trees in order to control the disease is not recommended because infected roots cannot be removed to a sufficient extent to reduce the inoculum. Furthermore, symptomless trees may already be infected. Felling as a method to stimulate sprouting from the stem base can be done, but the success will depend on the presence of living parts of the root system.

Because infection seems to occur predominantly via free water, it is recommended to avoid planting alders in areas that are flooded. Alders and surface water in contact with alders should not be exposed to contaminated soil or diseased plants.

Treatment of diseased plants with systemic fungicides proved effective in tests, but the practical application is very problematic due to the toxicity of fungicides in water. Furthermore, the risk of the development of resistant fungal strains has to be excluded by experiments. The same reservation has to be taken into account for wound paints containing fungicides based on octhilinone, which is toxic to fish.

\section{Literature Cited}

Appel, O. 1904. Über bestandsweises Absterben von Roterlen. Naturw. Z. Land-u. Forstw. 2:311-320.

Bansi. 1924. Zur Provenienzfrage der Roterle. Zeitschrift für Forst- und Jagdwesen, 166.

Brasier, C.M., J.Rose, and J.N.Gibbs. 1996. An unusual Phytophthora associated with widespread alder mortality in Britain. Plant Path. 44:999-1007. 
Brasier, C.M., and R.G. Strouts. 1976. New records of Phytophthora on trees in Britain, 1. Phytophthora root rot and bleeding canker of horse chestnut (Aesculus hippocastanum L.). Eur. J. For. Path. 6:129-136.

Cech, T. L. 1996. Phytophthora-Krankheit an Erle in Österreich. Forstschutz Aktuell 19/20:14-16.

Day, W.R. 1938. Root-rot of sweet chestnut and beech caused by species of Phytophthora, 1. Cause and symptoms of disease: Its relation to soll conditions. Forestry 12:101-116.

Domanski S., and T. Kowalski 1987. Fungi occurring on forests injured by air pollutants in the Upper Silesia and Cracow industrial regions. $X$. Mycoflora of dying young trees of Alnus incana. Eur. J. For. Path. 17(6):337-348.

Forestry Commission. 1997. Phytophthora Disease of Alder. Forestry Commission 1997, Environment Agency, UK.

Gibbs, J.N. 1995. Phytophthora root disease of alder in Britain. OEPP/EPPO Bulletin 25:661-664.

Gregory, S., G. MacAskill, and T. Winter. 1996. Crown thinning and dieback of alder in northern Britain. Research Information Note 283, Forestry Commission, $4 \mathrm{pp}$.

Hartmann, G. 1995. Wurzelhalsfäule der Schwarzerle (Alnus glutinosa)-Eine bisher unbekannte Pilzkrankheit durch Phytophthora cambivora (Collar rot of common alder caused by Phytophthora cambivora. Forst und Holz 50(18)555-557.

Lonsdale, D. 1996. Personal communication.

Münch, E. 1932. Über Standortsrassen der Waldbäume.

Beih. z. Bot. Centralbl. 49 Suppl., 292.

Münch, E. 1936. Das Erlensterben. Forstwiss. Cbl. 58:173-194, 230-248.

Nypels. 1900. Une maladie epidemique de l'aune commune (Alnus glutinosa Gaertn.). Bull. de la Soc. belg. de Microscopie 1900.

v. Oertzen. 1901. Die Krankheit der Roterie in Mecklenburg-Schwerin. Forstwiss. Cbl. 23:110.

Rostrup, E. 1889. Untersuchungen über den Angriff der Schmarotzerpilze auf Waldbäume in den Jahren 1883-1888. P.E. Müllers Tidskrift f. Skorbrus. 20:224.

Thinggaard, K. 1996. Svampen Phytophthora I Elletraeer. Skovens Sundhed 3:132-133.

Truter, S.J. 1947. Een voorlopig onderzoek naar de insterving van Alnus glutinosa (L.) Gaertner. Thesis, Univ. Utrecht, $110 \mathrm{pp}$.

Van Dijk K. 1996. Personal communication.

\author{
Federal Forest Research Centre \\ Institute of Forest Protection \\ Seckendorff -Gudent-Weg 8 \\ A-1131 Vienna, Austria
}

Résumé. Dans plusieurs communautés européennes, l'aulne (Alnus glutinosa et $A$. incana) poussant le long des cours d'eau est frappé d'un dépérissement qui est imputable à une nécrose des tiges causée par le Phytophthora. Au début on a cru à une forme de Phytophthora cambivora, mais des différences morphologiques ainsi que son homothallisme ont plutôt indiqué la présence d'une nouvelle espèce. La forte pathogénicité sur l'Alnus glutinosa et l'A. incana a été prouvée par des expériences en Grande-Bretagne, alors que seulement quelques cas ont été rapportés au Danemark, en France, en Allemagne, en Irlande et aux Pays-Bas. En Autriche, un dépérissement de l'A. glutinosa a été observé en 1986 et 1996. Les symptômes se manifestent simultanément par un dépérissement de la cime, précédé par des feuilles anormalement petites, des nécroses sur les tiges et des exsudats de l'écorce formant des taches goudronneuses. Des fissures avec de gros cals cicatriciels à la base de la tige laissent suggérer des attaques antérieures ou des blessures mécaniques causées avant l'infection. À certains endroits, le Phytophthora a été isolé et il présentait de grandes similarités avec les souches britanniques. De plus, des maladies de l'écorce ont aussi été identifiées; parmi elles, Phomopsis alnea, Ophiovalsa suffusa, Pleomassaria holoschista et Pezicula cinnamomea. Des prédispositions probables telles que des périodes de sécheresse suivies de fortes averses et de sévères gelées hivernales sont proposées et discutées ainsi que des mesures pratiques de contrôle.

Zusammenfassung. In Europa tritt seit 1993 ein Absterben von Schwarzerlen, Grauerlen und Italienischen Erlen auf, das von einer neuen Phytophthora - Art verursacht wird. Letztere wurde in Großbritannien entdeckt und steht Phytophthora cambivora nahe, ist, wie Tests in Großbritannien, Holland und Deutschland ergeben haben, hoch pathogen an allen drei Erlenarten. In Dänemark, Deutschland, Frankreich, Holland, Österreich und Schweden sind bisher nur lokale Krankheitsherde bekannt, hingegen tritt sie in Großbritannien epidemisch auf. Die Krankheit manifestiert sich in einem mehr oder minder simultanen Kronensterben als Folge der Entstehung einer Rindennekrose an der Stammbasis. Ein gemeinsames Auftreten des Kronensterbens und von Teerflecken im unteren Stammbereich gilt als zuverläßliches Indiz für das Phytophthora-Erlensterben, wenn auch der Letztnachweis nur durch Isolierungsreihen erfolgen kann. Die durch Phytophthora hervorgerufene Nekrose entsteht mehrheitlich unmittelbar im Bereich der Tag/Nacht-Zone und breitet sich stammaufwärts so wie in periklinaler Richtung aus. Der Infektionsmodus ist noch nicht ganz klar, doch dürften wie bei Phytophthora üblich, begeißelte Sporen als Inokulum fungieren, die im Wasser verbreitet werden, was das überwiegende Vorkommen der Krankheit an Erlen im Nahbereich von Flüssen und Bächen erklärt. Mechanische 
Verletzungen des Stammanlaufes sind als Eintrittspforte der Infektion nicht auszuschlißen, wobei diesbezügliche Untersuchungen noch nicht abgeschlossen sind. Eine Prädisposition der Erlen durch lang anhaltenden Trockenstre $ß$ und nachfolgende Staunässe ist ebenfalls nicht auszuschließen, doch konnte dies bisher nicht als einheitliche Ursache nachgewiesen werden, da die standörtlichen Klimaverhätnisse vor Ausbruch der Krankheit durchaus unterschiedlich waren. Das gleiche gilt für Frost, wie das gehäufte Auftreten absterbender Erlen in Österreich während der Jahre 1985-1986 in ausgesprochenen Kaltluftseen zeigte, bei dem nahezu gleiche Symptome beobachtet wurden wie beim gegenwärtigen Phytophthora-Erlensterben. Als weitere mögliche Vorschädigung kommt die Nährstoffbelastung der Gewässer infrage. So konnte in Großbritannien eine allerdings schwache Korrelation zwischen den Erlenschäden und insbesondere Nitrat nachgewiesen werden. Wäre dies die Hauptursache, so müßten die europäischen Länder in den nächsten Jahren mit Epidemien als Konsequenz einer langjährigen, zunehmenden Streßbelastung der Erlen rechnen. Die Schäden treten allerdings auch an unbelasteten Gewässern auf. So bleiben noch viele Fragen offen, so daß das Erlensterben in den kommenden Jahren Gegenstand intensiver Untersuchungen sein wird. Eine chemische Bekämpfung des Erlensterbens ist nur an Erlen mit noch lebenden Wurzelsystemen sinnvoll. Die Hauptproblematik liegt hier aber bei der Toxizität der meisten gegen Phytophthora wirksamen Fungizide, die im Nahbereich von Gewässern nur sehr eingeschänkt angewendet werden können. Die wichtigste Maßnahme ist derzeit die Vermeidung der Verschleppung infektiösen Materials bei Neupflanzungen oder durch Erdmaterial bei Uferbefestigungen.
Resumen. En varios paises europeos el aliso (Alnus glutinosa y $A$. incana) que crece a lo largo de los ríos, es afectado por una declinación, la cual está relacionada a la necrosis del tronco causada por Phytophthora. Se pensó primero que era una forma de Phytophthora cambivora, pero las diferencias morfológicas así como su homotallismo indican una nueva especie. La elevada patogenia en Alnus glutinosa y $A$. incana ha sido probada con experimentos en Gran Bretaña, Holanda y Alemania. En la actualidad, la enfermedad está dispersa en Gran Bretaña, mientras en Dinamarca, Francia, Alemania, Irlanda, Holanda y Suiza solamente se han reportado unos pocos casos. En Austria, la declinación de $A$. glutinosa fue observada en 1986 y 1996. Los síntomas incluyen simultánea declinación de la corona, precedida por hojas anormalmente pequeñas, necrosis del tallo y exudados de la corteza resultante en manchas. Las grietas en la base del tronco con fuerte formación de callo, sugieren ataques anteriores o daños mecánicos antes de la infección. En varios casos Phytophthora fue aislado, mostrando alta similitud con filamentos ingleses. Además fueron identificados los hongos atacantes de la corteza, entre ellos Phomopsis alnea, Ophiovalsa suffusa, Pleomassaria holoschista, y Pezicula cinnamome. Probables predisposiciones tales como periodos de sequia seguidos de lluvias pesadas, y severas heladas de invierno, son discutidas, como también medidas prácticas de control. 